\title{
Transformed Marginal Zone Lymphoma to Diffuse Large B-Cell Lymphoma
}

National Cancer Institute

\section{Source}

National Cancer Institute. Transformed Marginal Zone Lymphoma to Diffuse Large B-

Cell Lymphoma. NCl Thesaurus. Code C156699.

Histologic transformation of an indolent marginal zone lymphoma to an aggressive

diffuse large B-cell lymphoma. 